\title{
Development and evaluation of multi millet thresher
}

\author{
K. P. Singh*, Rahul R. Poddar, K. N. Agrawal, Smrutilipi Hota and Mukesh K. Singh \\ Agricultural Mechanization Division, Central Institute of Agricultural Engineering, Bhopal-462038, (Madhya Pradesh), \\ INDIA \\ *Corresponding author. E-mail: kp_singh24@yahoo.com
}

Received: March 14, 2015; Revised received: October 21, 2015; Accepted: November 18, 2015

\begin{abstract}
In tribal areas of India, traditional methods of threshing of minor millets like little millet (Panicum sumatrense), $\mathrm{M}_{1}$, kodo millet (Paspalum scrobiculatum), $\mathrm{M}_{2}$, foxtail millet (Setaria italica), $\mathrm{M}_{3}$, proso millet $(P$. miliaceum), $\mathrm{M}_{4}$, barnyard millet (Echinochloa frumantacea), $\mathrm{M}_{5}$, finger millet (Eleusine coracana), $\mathrm{M}_{6}$ is done of beating by sticks or treading out the crop panicle under the feet of oxen. This operation is most time consuming, labour intensive, drudgery prone, uneconomical, lower output and obtain low quality products. A thresher for these millet crops was developed and optimization of the operating parameters with little millet was done by using Response surface methodology (RSM). The optimized parameters were $7.79 \%$ (d.b) moisture content, $105 \mathrm{kgh}^{-1}$ feed rate, $625 \mathrm{rpm}$ cylinder speed, $5 \mathrm{~mm}$ threshing sieve size which gave maximum threshing efficiency of $95.13 \%$ and cleaning efficiency of $94.12 \%$. After optimization of parameters the thresher was tested for threshing of all the six minor millets with proper adjustments of sieve. Threshing capacity of $M_{1}, M_{2}, M_{3}, M_{4}, M_{5}$ and $M_{6}$ were obtained as 89, 137, 140, 91, 88 and 99 $\mathrm{kg} / \mathrm{h}$, respectively with more than $96 \%$ threshing efficiency and less than $2 \%$ broken grain.
\end{abstract}

Keywords: Cleaning efficiency, Multi millet thresher, Shear and impact cutting, Threshing efficiency

\section{INTRODUCTION}

Millets are very important food crop of tribal people and believed to be first domesticated cereal crop which is mostly grown in tribal and hilly areas of India and many Asian and African nations (Gbabo et al., 2013). These crops are grown in rain fed areas and temperature more than $20^{\circ} \mathrm{C}$ where other crops yield are very poor and are less prone to disease and pests. In India, millets are major staple food in the state of Uttarakhand, Chhattisgarh, Tamil Nadu, Odisha and Karnataka where these are grown widely with yield as high as $3 \mathrm{t} / \mathrm{ha}$. Maximum production (thousand tonnes), productivity $(\mathrm{kg} / \mathrm{ha}$ ) and area of production (thousand ha) of different millets in India are of Finger millet (1964.9, 1179, 1641.6), followed by Barnyard millet (180.1, 863, 208.6), Kodo millet (146.3, 366, 399.4), Little millet $(113.2,364,310.9)$, Foxtail millet (62.9, 607, 103.7) and Proso millet $(26.4,556,47.5)$. Millets are very nutritious and important crop for balanced diet, rich in vitamins, protein, carbohydrate, minerals, fibers, iron, amino acid, phosphorus, magnesium, potassium and also good source of energy. The epidemiological evidences indicate that person on millet based diets have good resistance for degenerative diseases such as heart disease, diabetes, hypertension etc (Anonymous, 2001).

Traditionally in tribal and hilly areas, threshing of millet crop is done either beating by sticks or by treading out the crop panicle under the feet of oxen. These threshing operations are most time consuming, energy intensive (19.9 kJ/min), labour intensive, drudgery prone and uneconomical. The mechanized threshing of millets can reduce the drudgery of farmers/labours, improve the quality of product. With existing socio economic condition of millet growing tribal farmers, the large capacity threshers are inappropriate and even the small size thresher with large scale sophistication are difficult to be adopted (Singh et al., 2002). Worldwide number of studies have been done for threshing of various crops but a very few studies has been reported on millet threshing. Therefore, development of thresher for all millet crops was found necessary which can do threshing of all millets.

Physical properties of crop are very important for the design and development of machine. Singh et al. ( 2010) studied different physical properties of barnyard millet. Baryeh (2002) evaluated different physical properties of millets and expressed as function of moisture content between 5-22.5\%. (Singh et al., 2003) developed a thresher at Vivekananda institute of Hill Agriculture (ICAR), Almora, Uttarakhand, India and was modified at IIT, Kharagpur. It was observed that threshing of millet is better in case of combination of impact and shear on the crop. Therefore the machine for threshing of all six minor millets was developed on the principle of combination of shear and impact at Central Institute of Agricultural Engineering, Bhopal, India.

Many researchers have worked on the optimization of 
process parameters like milling, threshing (Singh et al., 2004; Tiwari et al., 2007; Singh et al., 2008). Ajav and Adejumo (2005) studied the performance evaluation by taking moisture content, cylinder speed and feed rate as independent parameter to obtain the maximum threshing efficiency. Kushwaha et al. (2005) developed an okra seed extractor and evaluated the effect of drum speed and moisture content on extracting efficiency. Singh et al. (2008) developed a pedal operated paddy thresher and optimized the independent parameter like drum speed for getting highest threshing efficiency. Similarly Singh et al., (2010) optimized the value of drum speed for threshing of finger millet.

Response surface methodology (RSM) is defined as the statistical method that uses quantitative data from an appropriate experimental design to determine and simultaneously solve multivariate equations. The main advantage of RSM is that it reduces the number of experiments needed to evaluate multiple parameters and their interactions. It was used successfully by many scientists for optimization of different parameters for different operations (Goyal et al., 2008; Singh et al., 2008; Ushakumari et al., 2007; Nath and Chattopadhyay, 2007). The present study was undertaken to use RSM to optimize the operational parameters: moisture content(MC), feed rate(FR), drum speed(DS), threshing sieve size(TSS) to maximize the threshing and cleaning efficiencies of the thresher.

\section{MATERIALS AND METHODS}

Raw material: Different millets like little, kodo, proso, foxtail, barnyard and finger millet of local varieties were collected from small village Patalkot/ Dhindhori tribal areas of MP. Physical properties of all millets (Table 1) were observed to suitable for the proper threshing of millet. The moisture content of the crops was kept 5 to $11 \%$ for performance analysis and digital moisture meter was used for this purpose.

Design and development of the thresher: A multi millet thresher was designed and developed for threshing of the millets based on the different properties of the minor millets. Developed machine works on the principle of impact and shear force acting on the ear head of the crop for the purpose of threshing of millets. The threshing drum was fitted with three rows of can- vas strips and three rows of cutting knives places alternately as some of the millet crop requires cutting action and some requires shear for complete threshing. The knives arrows provides impact cutting of crop stem during threshing and the canvas strip rows gives gentle abrasion and shear on the grain for removing the grains from the glumes. The threshing chamber is fitted with a sliding sieve which is allow repetitive impact and shear to complete detach of glumes from the grains which helps in complete threshing of millets.

Ergonomic consideration in the design of the thresher: In general these crops threshed inside the boundary of the house. The ergonomic and safety is very important especially for the use of tribal women worker. Ergonomic considerations were used in the design of thresher for safety of the worker. The length of the feeding chute was kept $900 \mathrm{~mm}$ as per IS: 9020-2002. Grip handles of threshing sieves were made as per inner grip diameter for better comfort of the worker. Shaker assembly for cleaning system was provided with packing for reduction of vibration and noise. Rubber transportation wheels instead of cast iron wheels were provided for easy transportation and for absorption of vibration during operation. The machine is attached with safety guards over power transmission system. A flapper was fitted in the feeding chute to arrest the dust which may create health problems of the worker.

Evaluation of multi millet thresher: The multi millet thresher prototype was evaluated after development. For the evaluation little millet crop was taken after harvesting. The crop was taken as the whole crop for threshing. But after the optimization the final thresher was tested with all six minor millets by taking only the ear heads of kodo millet, foxtail millet, barnyard millet and finger millet except little millet and proso millet as recommended by the tribal farmers. The feed rate was controlled manually by the help of a worker and maintained from 75 to $120 \mathrm{kgh}^{-1}$. They had to feed the whole crop as per requirement. A two hp, single phase electric motor was used as power source and the power is transmitted to the threshing drum, aspirator by the help of belt drive. For variation of drum speed from 500 to $1000 \mathrm{rev} / \mathrm{min}$ different size of pullies were used according to the requirement. The air flow rate was

Table 1. Specifications of the developed CIAE multi millet thresher.

\begin{tabular}{ll}
\hline Length & $2027 \mathrm{~mm}$ \\
Width & $1048 \mathrm{~mm}$ \\
Height & $1200 \mathrm{~mm}$ \\
Weight of the machine & $180 \mathrm{~kg}$ \\
Threshing chute length & $900 \mathrm{~mm}$ \\
Cost of the machine & Rs $45,000 /-$ \\
Power requirement & $2 \mathrm{hp}$, single phase electric motor \\
Machine noise level & $84 \mathrm{db}$ \\
Threshing capacity & $80-150 \mathrm{~kg} / \mathrm{h}$ (depending on millet comodity) \\
Dehulling capacity & $20-80 \mathrm{~kg} / \mathrm{h}$ (depending on millet comodity) \\
Pearling capacity of finger millet & $200-250 \mathrm{~kg} / \mathrm{h}$ \\
\hline
\end{tabular}


Table 2. Coded values and corresponding real values used in experimentation.

\begin{tabular}{lcccccc}
\hline Independent variable & Coded value & $-\boldsymbol{\alpha}(\mathbf{- 1 . 4 1 4})$ & $\mathbf{- 1}$ & $\mathbf{0}$ & $\mathbf{+ 1}$ & $\mathbf{+ \alpha ( + 1 . 4 1 4 )}$ \\
\hline Moisture content $\left(\mathrm{M}_{\mathrm{c}}\right), \% \mathrm{db}$ & Actual value & 3 & 5 & 7 & 9 & 11 \\
Feed rate $\left(\mathrm{F}_{\mathrm{r}}\right), \mathrm{kg} / \mathrm{h}$ & & 60 & 75 & 90 & 105 & 120 \\
Drum speed $\left(\mathrm{D}_{\mathrm{s}}\right), \mathrm{rpm}$ & 500 & 625 & 750 & 875 & 1000 \\
Threshing sieve size $\left(\mathrm{T}_{\mathrm{ss}}\right), \mathrm{mm}$ & & 3 & 5 & 7 & 9 & 11 \\
\hline
\end{tabular}

Table 3. Experimental design for thrshing of little millet using CCRD with four independent variables.

\begin{tabular}{|c|c|c|c|c|c|c|}
\hline \multirow[b]{2}{*}{ Run } & \multicolumn{4}{|c|}{ Independent variables } & \multicolumn{2}{|c|}{ Dependent variable } \\
\hline & $\begin{array}{l}\text { Moisture content } \\
\left(\mathbf{M}_{\mathrm{c}}\right), \%(\mathbf{d b})\end{array}$ & $\begin{array}{c}\text { Feed Rate } \\
\left(F_{r}\right), \mathrm{kg} / \mathrm{h}\end{array}$ & $\begin{array}{c}\text { Drum Speed } \\
\left(D_{\mathrm{s}}\right), \mathrm{rpm}\end{array}$ & $\begin{array}{l}\text { Threshing Sieve } \\
\text { Size }\left(\mathrm{T}_{\mathrm{ss}}\right), \mathrm{mm}\end{array}$ & $\begin{array}{c}\text { Threshing } \\
\text { efficiency } \\
\left(\mathrm{T}_{\mathrm{e}}\right), \%\end{array}$ & $\begin{array}{r}\text { Cleaning } \\
\text { efficiency } \\
\left(\mathrm{C}_{\mathrm{e}}\right), \%\end{array}$ \\
\hline 1 & $5(-1)$ & $75(-1)$ & $875(+1)$ & $5(-1)$ & 97 & 96 \\
\hline 2 & $7(0)$ & $90(0)$ & $750(0)$ & $11(+\alpha)$ & 92 & 93 \\
\hline 3 & $9(+1)$ & $105(+1)$ & $625(-1)$ & $9(+1)$ & 85 & 87 \\
\hline 4 & $9(+1)$ & $105(+1)$ & $875(+1)$ & $9(+1)$ & 90 & 89 \\
\hline 5 & $9(+1)$ & $75(-1)$ & $875(+1)$ & $5(-1)$ & 94 & 94 \\
\hline 6 & $5(-1)$ & $105(+1)$ & $875(+1)$ & $9(+1)$ & 93 & 91 \\
\hline 7 & $9(+1)$ & $75(-1)$ & $875(+1)$ & $9(+1)$ & 91 & 91 \\
\hline 8 & $9(+1)$ & $105(+1)$ & $875(+1)$ & $5(-1)$ & 96 & 93 \\
\hline 9 & $7(0)$ & $90(0)$ & $1000(+\alpha)$ & $7(0)$ & 99 & 97 \\
\hline 10 & $5(-1)$ & $75(-1)$ & $625(-1)$ & $9(+1)$ & 91 & 88 \\
\hline 11 & $7(0)$ & $90(0)$ & $750(0)$ & $7(0)$ & 90 & 96 \\
\hline 12 & $9(+1)$ & $105(+1)$ & $625(-1)$ & $5(-1)$ & 95 & 90 \\
\hline 13 & $7(0)$ & $60(-\alpha)$ & $750(0)$ & $7(0)$ & 96 & 93 \\
\hline 14 & $9(+1)$ & $75(-1)$ & $625(-1)$ & $5(-1)$ & 90 & 87 \\
\hline 15 & $11(+\alpha)$ & $90(0)$ & $750(0)$ & $7(0)$ & 84 & 86 \\
\hline 16 & $5(-1)$ & $105(+1)$ & $875(+1)$ & $5(-1)$ & 95 & 94 \\
\hline 17 & $9(+1)$ & $75(-1)$ & $625(-1)$ & $9(+1)$ & 88 & 92 \\
\hline 18 & $7(0)$ & $90(0)$ & $750(0)$ & $7(0)$ & 89 & 94 \\
\hline 19 & $7(0)$ & $120(+\alpha)$ & $750(0)$ & $7(0)$ & 94 & 90 \\
\hline 20 & $5(-1)$ & $75(-1)$ & $875(+1)$ & $9(+1)$ & 96 & 95 \\
\hline 21 & $7(0)$ & $90(0)$ & $750(0)$ & $7(0)$ & 94 & 93 \\
\hline 22 & $3(-\alpha)$ & $90(0)$ & $750(0)$ & $7(0)$ & 90 & 89 \\
\hline 23 & $7(0)$ & $90(0)$ & $750(0)$ & $3(-\alpha)$ & 93 & 96 \\
\hline 24 & $7(0)$ & $90(0)$ & $750(0)$ & $7(0)$ & 92 & 93 \\
\hline 25 & $7(0)$ & $90(0)$ & $500(-\alpha)$ & $7(0)$ & 96 & 89 \\
\hline 26 & $7(0)$ & $90(0)$ & $750(0)$ & $7(0)$ & 92 & 95 \\
\hline 27 & $5(-1)$ & $105(+1)$ & $625(-1)$ & $5(-1)$ & 95 & 90 \\
\hline 28 & $5(-1)$ & $75(-1)$ & $625(-1)$ & $5(-1)$ & 93 & 90 \\
\hline 29 & $7(0)$ & $90(0)$ & $750(0)$ & $7(0)$ & 92 & 90 \\
\hline 30 & $5(-1)$ & $105(+1)$ & $625(-1)$ & $9(+1)$ & 93 & 89 \\
\hline
\end{tabular}

maintained below the terminal velocity of the grains and above the terminal velocity of chaff. The speed of aspirator was maintained by the use of belt drive.

The moisture content was varied by adding of water to the sample. The samples were prepared by spraying the desired amount of distilled water to the samples, thoroughly mixed, sealed in separate polyethylene bags and then kept for a week for uniform distribution of moisture throughout the samples. Before each experiment required amount of samples were taken out and allowed to warm up to the room temperature (Goyal et al., 2008; Singh et al., 2010). The amount of water required for desired moisture content was calculated by the following equation (Karababa, 2006; Altuntas and Yildiz, 2007; Singh et al., 2010).

\section{$\mathrm{Q}=\frac{\mathrm{Wi}(\mathrm{Mf}-\mathrm{Mi})}{\mathbf{1 0 0}-\mathbf{m f}}$}

The evaluation was done by taking the required sample of $10 \mathrm{~kg}$ each time and the data were collected. Some formulas used for calculation of threshing efficiency, cleaning efficiency were,

Threshing efficiency $=$ threshed grains received from all the outlets with respect to total grain input expressed as percentage by mass.

$\mathrm{TE}=100$-percentage of unthreshed grains

Percentage of unthreshed grains

$$
Z=\frac{D}{A} \times 100
$$


Table 4. Analysis of variance for threshing efficiency.

\begin{tabular}{lllllll}
\hline Source & $\begin{array}{l}\text { Sum of } \\
\text { Squares }\end{array}$ & df & $\begin{array}{l}\text { Mean } \\
\text { Square }\end{array}$ & F Value & p- value $>$ F & Significant \\
\hline Model & 283.33 & 14 & 20.23 & 6.57 & 0.0004 & 0.0008 \\
$M_{c}$ & 54.00 & 1 & 54.00 & 17.54 & $0.8191 \mathrm{NS}$ \\
$F_{r}$ & 0.16 & 1 & 0.16 & 0.05 & 0.0053 \\
$D_{s}$ & 32.66 & 1 & 32.66 & 10.61 & 0.0033 \\
$T_{s s}$ & 37.50 & 1 & 37.50 & 12.18 & $0.5771 \mathrm{NS}$ \\
$M_{c} \times F_{r}$ & 1.00 & 1 & 1.00 & 0.32 & $0.5771 \mathrm{NS}$ \\
$M_{c} \times D_{s}$ & 1.00 & 1 & 1.00 & 0.32 & $0.0645 \mathrm{NS}$ \\
$M_{c} \times T_{s s}$ & 12.25 & 1 & 12.25 & 3.98 & $0.1746 \mathrm{NS}$ \\
$F_{r} \times D_{s}$ & 6.25 & 1 & 6.25 & 2.03 & $0.1079 \mathrm{NS}$ \\
$F_{r} \times T_{s s}$ & 9.00 & 1 & 9.00 & 2.92 & $0.5771 \mathrm{NS}$ \\
$D_{s} \times T_{s s}$ & 1.00 & 1 & 1.00 & 0.32 & 0.0029 \\
$M_{c}{ }^{2}$ & 38.67 & 1 & 38.67 & 12.56 & 0.0284 \\
$F_{r}{ }^{2}$ & 18.10 & 1 & 18.10 & 5.88 & 0.0006 \\
$D_{s}{ }^{2}$ & 56.67 & 1 & 56.67 & 18.41 & $0.5839 \mathrm{NS}$ \\
$T_{s s}{ }^{2}$ & 0.96 & 1 & 0.96 & 0.31 & 0.5402 \\
Lack of Fit & 30.66 & 10 & 3.06 & 0.98 & not significant \\
\hline
\end{tabular}

Table 5. Analysis of variance for cleaning efficiency.

\begin{tabular}{lllllll}
\hline Source & $\begin{array}{l}\text { Sum of } \\
\text { Squares }\end{array}$ & Df & Mean Square & \multicolumn{1}{c}{$\begin{array}{l}\text { Value } \\
\text { Value }\end{array}$} & $\begin{array}{l}\text { p-value } \\
\text { Prob }>\text { F }\end{array}$ & Significant \\
\hline Model & 223.33 & 14 & 15.95 & 5.79 & 0.0008 & $0.0679 \mathrm{NS}$ \\
$M_{c}$ & 10.67 & 1 & 10.67 & 3.87 & $<0.0001$ & \\
$F_{r}$ & 88.17 & 1 & 88.17 & 32.00 & 0.0428 \\
$D_{s}$ & 13.5 & 1 & 13.5 & 4.9 & $\mathrm{NS}$ \\
$T_{s s}$ & 0.00 & 1 & 0.00 & 0.00 & $0.2469 \mathrm{NS}$ \\
$M_{c} \times F_{r}$ & 4.00 & 1 & 4.00 & 1.45 & $0.7674 \mathrm{NS}$ \\
$M_{c} \times D_{s}$ & 0.25 & 1 & 0.25 & 0.091 & $0.2469 \mathrm{NS}$ \\
$M_{c} \times T_{s s}$ & 4.00 & 1 & 4.00 & 1.45 & $0.1528 \mathrm{NS}$ \\
$F_{r} \times D_{s}$ & 6.25 & 1 & 6.25 & 2.27 & $0.1528 \mathrm{NS}$ \\
$F_{r} \times T_{s s}$ & 6.25 & 1 & 6.25 & 2.27 & 0.0001 \\
$D_{s} \times T_{s s}$ & 70.58 & 1 & 70.58 & 25.61 & $0.076 \mathrm{NS}$ \\
$M_{c}{ }^{2}$ & 10.01 & 1 & 10.01 & 3.63 & $0.4808 \mathrm{NS}$ \\
$F_{r}{ }^{2}$ & 1.44 & 1 & 1.44 & 0.52 & $0.652 \mathrm{NS}$ \\
$D_{s}{ }_{\text {Lack of Fit }}$ & 0.58 & 1 & 0.58 & 0.21 & 0.8606 \\
\hline
\end{tabular}

Where, D =Quantity of unthreshed grains collected from all outlets per unit time

$\mathrm{A}=$ Total grain input per unit time

Cleaning efficiency $=$ Clean grain received at main grain outlet with respect to the total grain mixture received at main grain outlet expressed as percentage by mass.

$$
\mathrm{CE}=\frac{\mathrm{M}}{\mathrm{F}} \times 100
$$

Where, $\mathrm{M}=$ Quantity of clean grain obtained from the sample taken at main grain outlet.

$\mathrm{F}=$ Total quantity of the sample taken at main grain outlet.

Experimental design: Central Composite Rotatable Design (CCRD) (Rastogi et al., 1998; Singh et al., 2011) was considered as experimental design with four independent parameters moisture content, feed rate, threshing drum speed and threshing sieve size for optimization. The responses were obtained in terms of threshing and cleaning efficiency and optimized by use of RSM.
CCRD for optimization of operational parameters: The operational parameters were fixed at 5 levels (Table 2) as per CCRD and a total number of 30 experiments were carried out (Table 3 ). Seven repeated experiments were conducted at the central points of the coded variables to calculate the error sum of squares and the lack of fit of the developed regression equation between the responses and independent variables.

The parameters were optimized by using Design expert 7.0.0 software, which gave optimum values based on experimented results.

\section{RESULTS AND DISCUSSION}

Threshing efficiency: Analysis of variance was conducted for threshing efficiency and is presented in the table 4. The ANOVA data shows high F value (6.58) which implies the model to be significant at $0.1 \%$ level of significance. The linear effect of moisture content was highly significant on threshing efficiency at $0.1 \%$ 


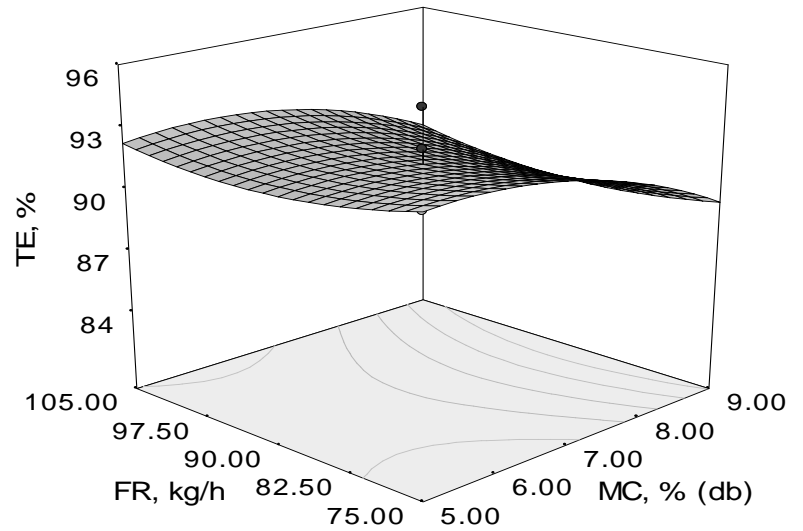

(a)

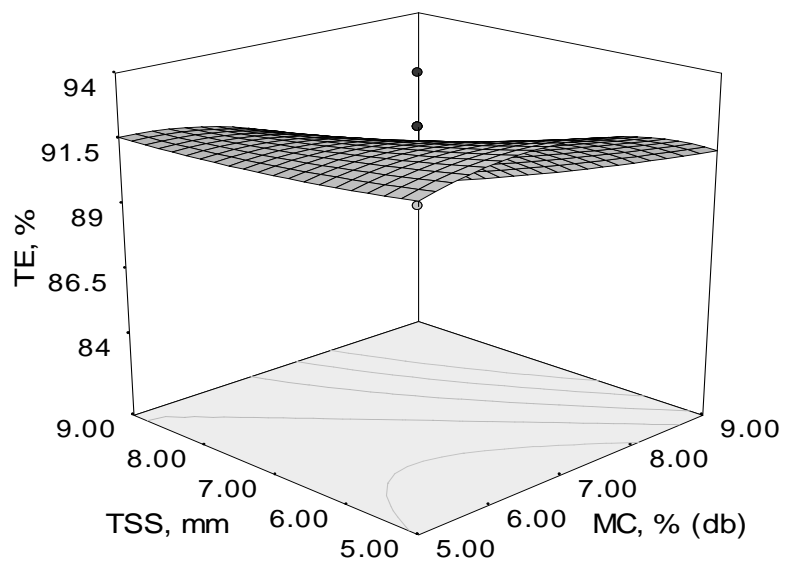

(b)

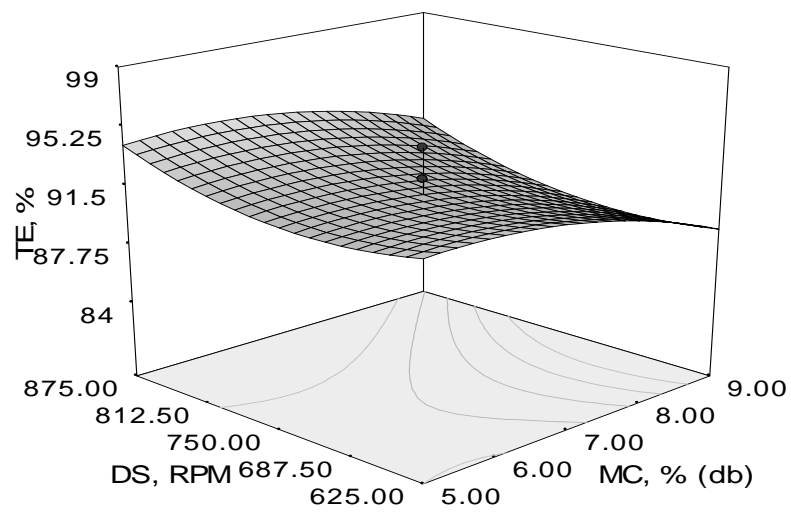

(c)

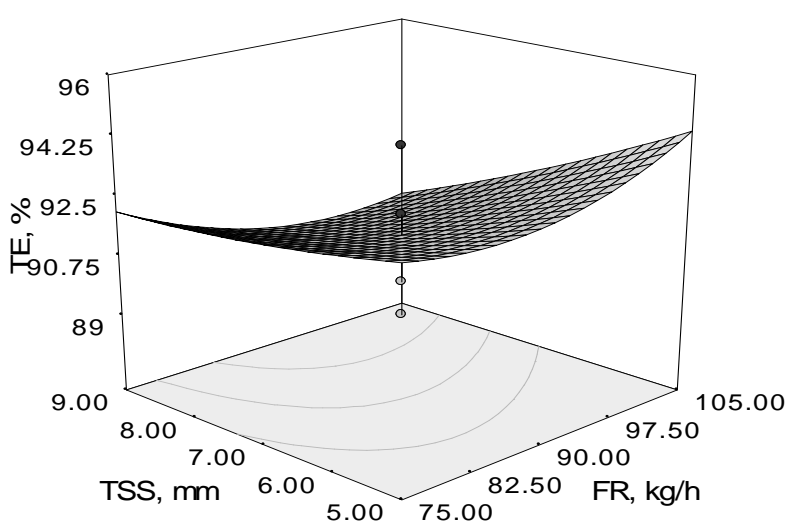

(d)

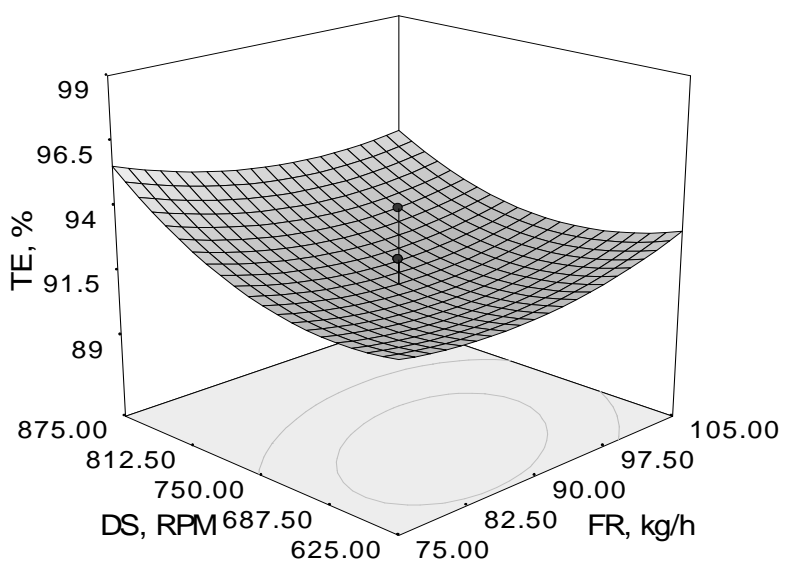

(e)

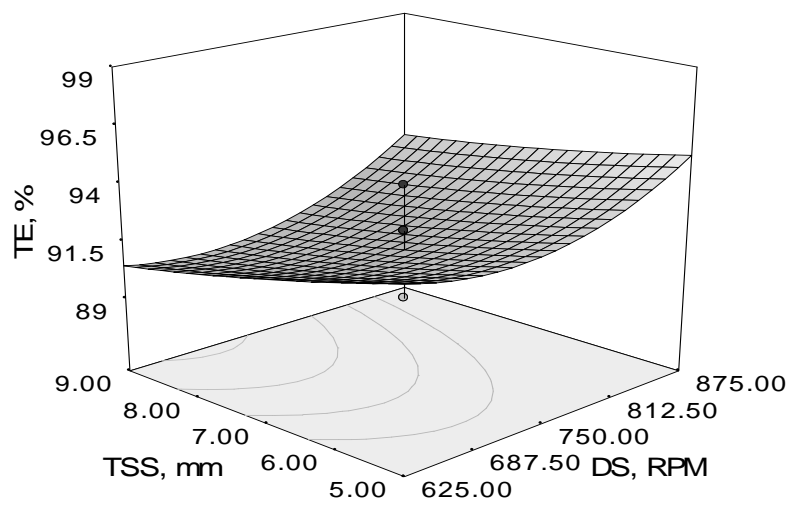

$(f)$

Fig. 1. Response surface contours for threshing efficiency of millets as a function of (a) Feed rate moisture content, (b) threshing sieve size and moisture content, $(c)$ drum speed and moisture content, $(d)$ threshing sieve size and Feed rate, $(e)$ drum speed and Feed rate and (f) threshing sieve size and drum speed.

level of significance and effect of drum speed and threshing sieve size were significant at $1 \%$ level of significance. The quadratic term of drum speed is highly significant $(\mathrm{p}<0.001)$ and moisture content $(\mathrm{p}<0.01)$ and feed rate $(0.05)$ had significant effect on threshing efficiency. The lack of fit was obtained non significant on threshing efficiency. No significant effect was found in case of all the interactions of the variables. The regression equation obtained for the response threshing efficiency with four independent variables neglecting the high error generating terms was presented in the equation 5 .

$\mathrm{Te}=+91.50-1.50 \quad \mathrm{M}_{\mathrm{c}}+1.17 \quad \mathrm{D}_{\mathrm{s}}-1.25 \mathrm{~T}_{\mathrm{ss}}-1.19$

$\mathrm{M}_{\mathrm{c}}^{2}+0.81 \mathrm{~F}_{\mathrm{r}}^{2}+1.44 \mathrm{D}_{\mathrm{s}}^{2}$.

Where, $T_{e}=$ Threshing efficiency, $\%$

$M_{c}=$ Moisture content, $\%$ (d.b)

$D_{s}=$ Drum speed, rev/min

$T_{s s}=$ Threshing sieve size, $\mathrm{mm}$

$F_{r}=$ Feed Rate, $\mathrm{kgh}^{-1}$ 


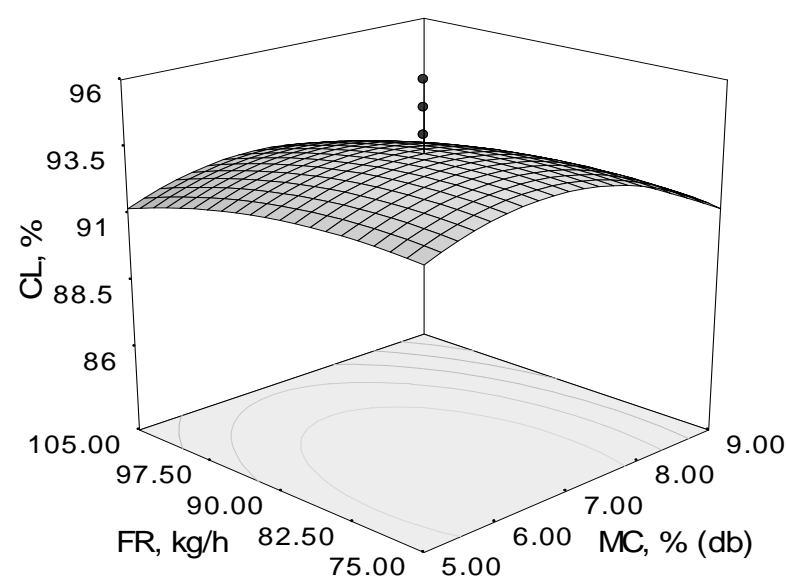

(a)

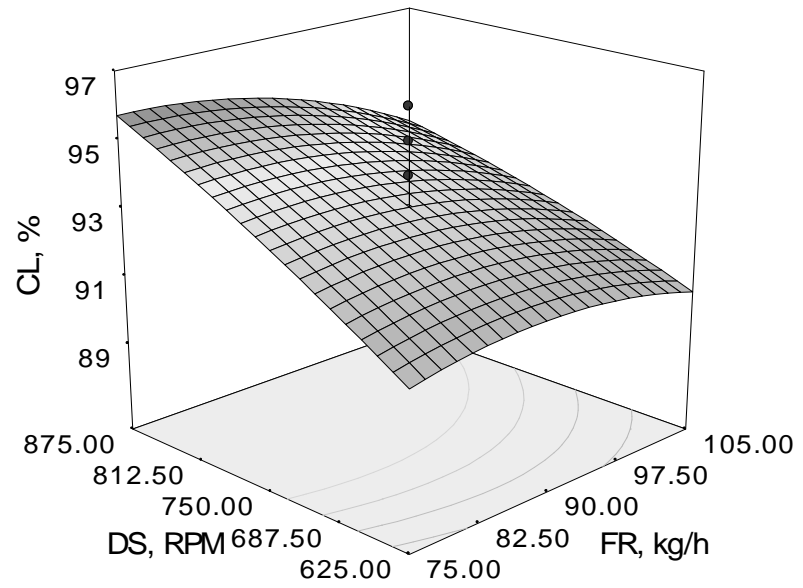

(b)

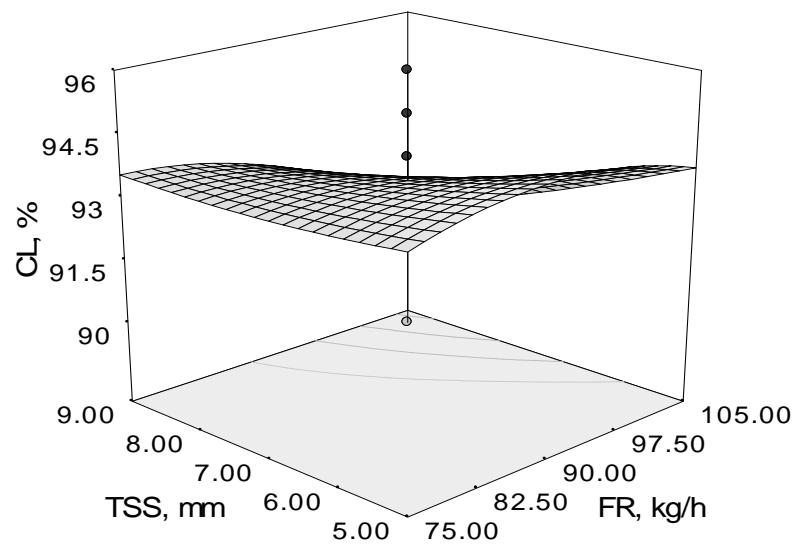

(c)

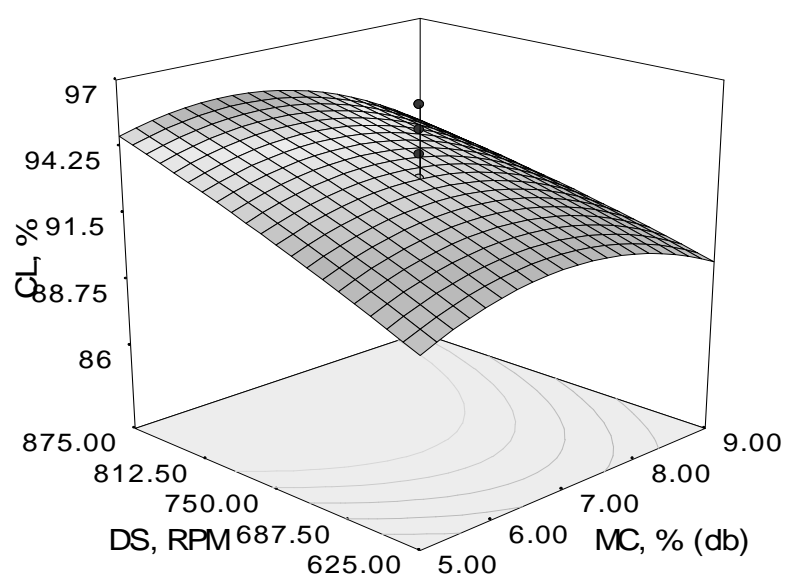

(d)

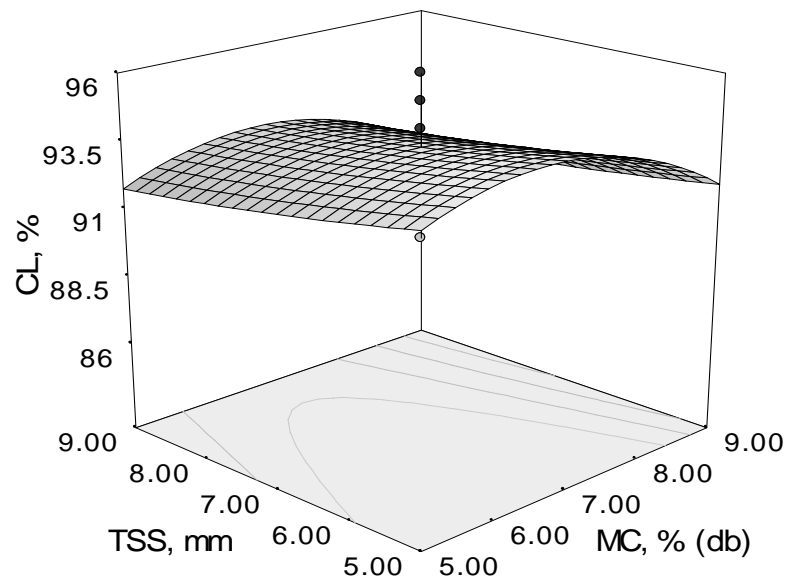

(e)

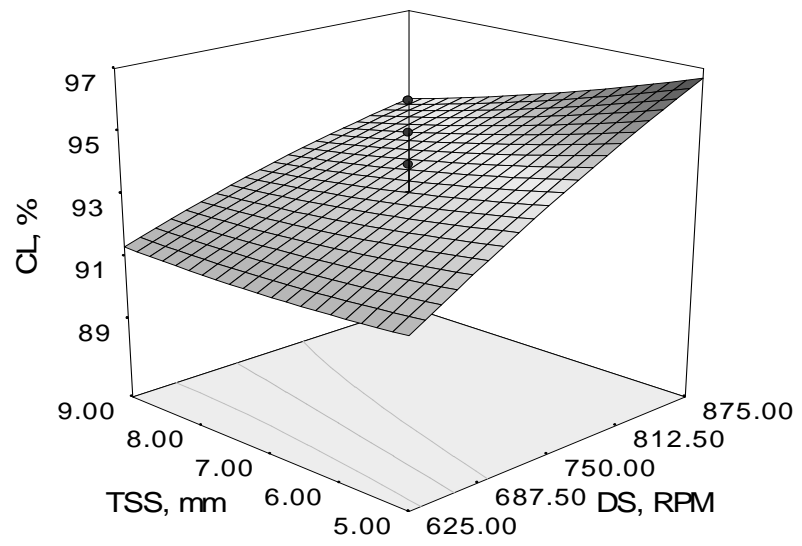

$(f)$

Fig. 2. Response surface contours for cleaning efficiency of millets as a function of (a) Feed rate and moisture content, (b) drum speed and feed rate, (c) threshing sieve size and feed rate (d) drum speed and moisture content, (e) threshing sieve size and moisture content and (f) threshing sieve size and drum speed.

Response surface plots and contours of threshing efficiency as function of moisture content, feed rate, drum speed and threshing sieve size are showed in Fig $1 \mathrm{a}, \mathrm{b}$, $c, d$, e and $f$. Threshing efficiency was found slow decreased with increase of moisture content from 5 to $7 \%$ and decrease was rapid thereafter within the experi- mental range of feed rates, threshing sieve size and drum speed (Fig. 1a, 1b, 1c). It can be observed from Fig. 1a that at a fixed feed rate of $75 \mathrm{kgh}^{-1}$ threshing efficiency was decreased from 92 to $91.5 \%$ slowly as the moisture content was increased up to $7 \%$ and decreased rapidly thereafter up to $90 \%$. Kamble et al. 
Table 6. Comparison of physical and threshing parameters of selected minor millets.

\begin{tabular}{|c|c|c|c|c|c|c|c|c|}
\hline Millets & $\begin{array}{l}\text { Dia } \\
(\mathbf{m m})\end{array}$ & $\begin{array}{l}\text { Sphericity } \\
\text { (fraction) }\end{array}$ & $\begin{array}{l}\text { Bulk } \\
\text { density } \\
\left(\mathbf{k g} / \mathbf{m}^{3}\right)\end{array}$ & $\begin{array}{l}\text { Thousand } \\
\text { grain } \\
\text { weight } \\
\text { (gm) }\end{array}$ & $\begin{array}{l}\text { Thresh- } \\
\text { ing ca- } \\
\text { pacity } \\
\text { (kg/h) }\end{array}$ & $\begin{array}{l}\text { Thresh- } \\
\text { ing effi- } \\
\text { ciency } \\
(\%)\end{array}$ & $\begin{array}{l}\text { Broken } \\
\text { grain } \\
(\%)\end{array}$ & $\begin{array}{l}\text { Clean- } \\
\text { ing effi- } \\
\text { ciency } \\
(\%)\end{array}$ \\
\hline $\begin{array}{l}\text { Panicum suma- } \\
\text { trense }(M 1)\end{array}$ & $2.26^{\mathrm{b}}$ & $0.481^{\mathrm{a}}$ & $815.0^{c}$ & $2.08^{a}$ & $88.7^{a}$ & $97.57^{\mathrm{a}}$ & $1.70^{\mathrm{b}}$ & $97.13^{\mathrm{a}}$ \\
\hline $\begin{array}{l}\text { Paspalum scrobi- } \\
\text { culatum (M2) }\end{array}$ & $3.41^{\mathrm{b}}$ & $0.818^{\mathrm{e}}$ & $747.0^{\mathrm{a}}$ & $4.20^{\mathrm{d}}$ & $116.7^{\mathrm{b}}$ & $99.33^{\mathrm{b}}$ & $0.50^{\mathrm{a}}$ & $98.96^{\mathrm{b}}$ \\
\hline $\begin{array}{l}\text { Setaria italic } \\
(M 3)\end{array}$ & $2.35^{\mathrm{b}}$ & $0.512^{\mathrm{b}}$ & $753.7^{\mathrm{a}}$ & $2.39^{\mathrm{b}}$ & $95.3^{\mathrm{a}}$ & $99.40^{\mathrm{b}}$ & $1.20^{\mathrm{b}}$ & $99.12^{\mathrm{b}}$ \\
\hline $\begin{array}{l}\text { Panicummili- } \\
\text { aceum (M4) }\end{array}$ & $1.95^{\mathrm{a}}$ & $0.485^{\mathrm{a}}$ & $825.3^{c}$ & $2.32^{\mathrm{b}}$ & $95.0^{\mathrm{a}}$ & $97.33^{\mathrm{a}}$ & $1.60^{\mathrm{b}}$ & $96.98^{\mathrm{a}}$ \\
\hline $\begin{array}{l}\text { Echinoch- } \\
\text { loa frumantacea } \\
(\text { M5) }\end{array}$ & $2.32^{\mathrm{b}}$ & $0.544^{\mathrm{c}}$ & $895.3^{\mathrm{d}}$ & $3.35^{\mathrm{c}}$ & $108.3^{\mathrm{b}}$ & $96.33^{\mathrm{a}}$ & $0.54^{\mathrm{a}}$ & $95.89^{\mathrm{a}}$ \\
\hline $\begin{array}{l}\text { Eleusine cora- } \\
\text { cana }(M 6)\end{array}$ & $1.63^{\mathrm{a}}$ & $0.681^{\mathrm{d}}$ & $802.0^{\mathrm{b}}$ & $2.35^{\mathrm{b}}$ & $102.0^{\mathrm{a}}$ & $99.40^{\mathrm{b}}$ & $0.00^{\mathrm{a}}$ & $99.27^{\mathrm{b}}$ \\
\hline
\end{tabular}

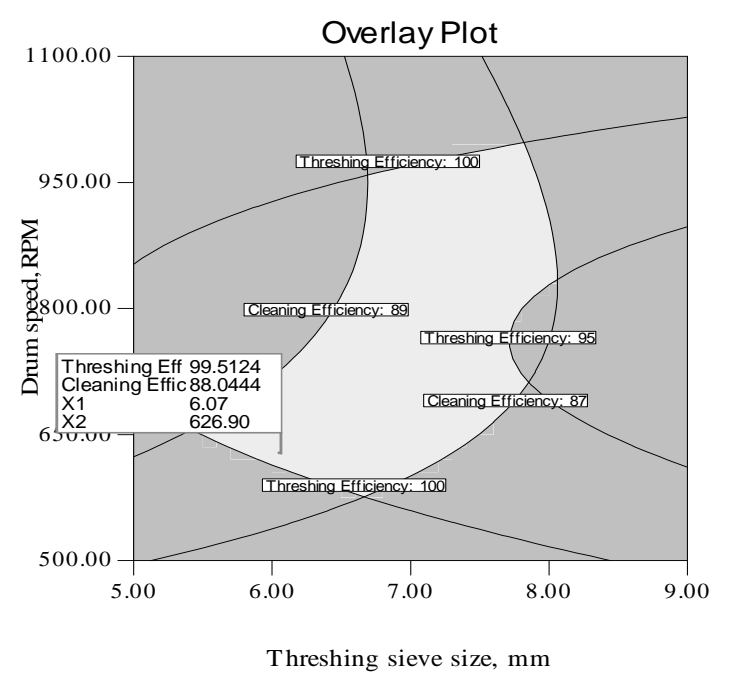

(a)

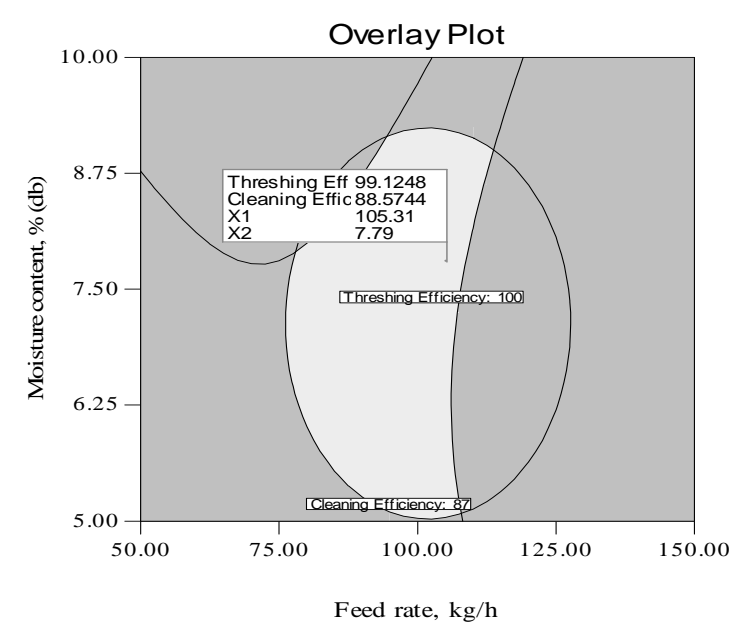

(b)

(2003) conducted the study of pearl millet thresher and got the reduced threshing efficiency with increase of moisture content because high moisture content in-

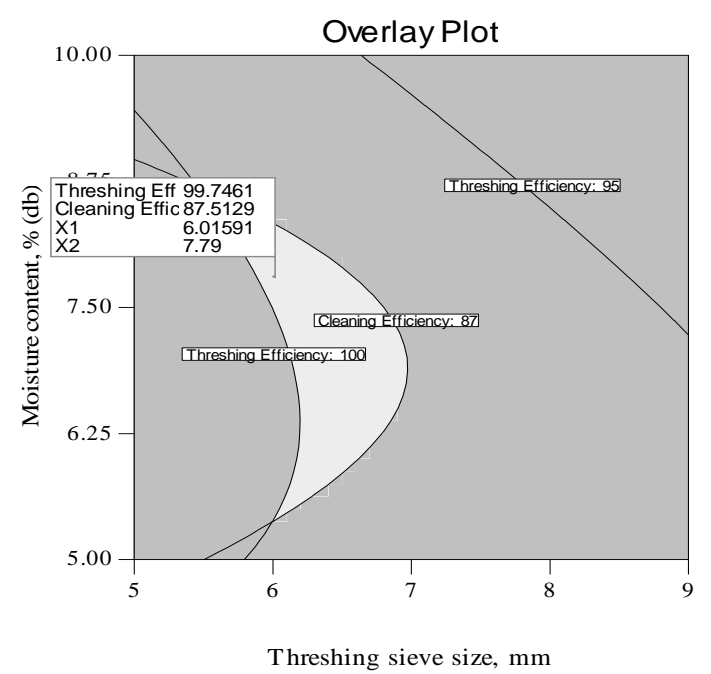

(c)

Fig. 3. Super imposed contours plots of (a) drum speed and threshing sieve size, (b) moisture content and feed rate and (c) moisture content and threshing sieve size.

creased the plasticity of the grain. Bansal and Lohan (2009) obtained higher threshing efficiency at lower moisture content during threshing of seed crops. Kushwaha et al. (2005) developed an Okra seed extractor and evaluated at different moisture content from which they got the result as extracting efficiency was decreased with increase of moisture content. Fulani et al. (2013) resulted that higher threshing efficiency observed at lower moisture content in case of cowpea. Increase in threshing efficiency was observed very slowly with increase of feed rate within all experimental range of moisture content, threshing sieve size and drum speed (Fig. 1a, 1d, 1e). Abo-ElNaga et al. (2015) found increased threshing efficiency with increase of feed rate. In the present study, threshing efficiency was found to be increased rapidly with increased of drum speed with all experimental range of 
moisture content, feed rate and threshing sieve size (Fig. 1c, 1e, 1f). At a fix moisture content of $5 \%$ the threshing efficiency was increased from 88 to $95 \%$ as the drum speed increased from 625 to $875 \mathrm{rev} / \mathrm{min}$. This may be due to more impact action of the drum per unit time on the crop. Kamble et al., 2003 studied the effect of drum speed on threshing of pearl millet. It was observed that increase in drum speed increased the threshing efficiency in a high range. Bansal and Lohan ( 2009) also found higher threshing efficiency at high drum speed in case of seed crops. Ajav and Adejumo (2005) studied performance evaluation of an okra thresher and got the similar result as increase in cylinder speed increased the threshing efficiency. Singh et al., 2008 studied the effect of threshing drum speed on threshing performances of pedal operated VL paddy thresher and got the same result. Sinha et al. (2007) studied the effect of drum speed on chickpea seed crop threshing, Fulani et al. (2013) also found similar result that threshing efficiency increased with increase of drum speed. Simonyan and Imokheme (2008) studied the effect of drum speed on sorghum threshing and they also got similar observations of increased threshing efficiency with increase of drum speed as in present study (Fig. 1c). Threshing efficiency was found very slowly decreased with increased of threshing sieve size within all the experimental range the moisture content, feed rate and drum speed (Fig. 1b, 1d, 1f). If we fix the feed rate at $75 \mathrm{kgh}^{-1}$ threshing, efficiency was found decreased from 91 to $90 \%$ as the sieve size increased from 5 to $9 \mathrm{~mm}$ (Fig. 1d). The sieve size was selected for making suitable for all six minor millet according to their size. Higher size of sieve could not give necessary impact and caused grain loss.

Cleaning efficiency: Analysis of variance for response surface variable cleaning efficiency is presented in the Table 5. The ANOVA data shows that the model is significant at $0.1 \%$ level of significance whose $F$ value is 5.8. The linear effect of feed rate on cleaning efficiency was highly significant ( $p<0.001$ ). The effect of drum speed is significant at $5 \%$ level of significance. The interaction of drum speed and threshing sieve size had significant effect on cleaning efficiency at $0.1 \%$ level of significance. The effect of moisture content and threshing sieve size had no significant effect on cleaning efficiency. The effect of the interactions except drum speed and threshing sieve size on cleaning efficiency were non significant. All the quadratic terms of independent parameters had no significant effect on cleaning efficiency. The regression equation obtained for cleaning efficiency as the function of four independent variables neglecting the high error generating terms was presented in the equation 6 .

$\mathrm{Ce}=+93.50-0.67 \mathrm{Fr}+1.92 \mathrm{Ds}-0.62 \mathrm{Ds} \mathrm{x}$ Tss

Where, Te $=$ Threshing efficiency, $\%$

$\mathrm{Mc}=$ Moisture content, $\%$

Ds $=$ Drum speed, rev/min

Tss $=$ Threshing sieve size, $\mathrm{mm}$
$\mathrm{Fr}=$ Feed Rate, $\mathrm{kgh}^{-1}$

Response surface plots and contours of cleaning efficiency as function of moisture content, feed rate, drum speed and threshing sieve size are showed in Fig 2 a, b, $\mathrm{c}, \mathrm{d}$, e and $\mathrm{f}$. Cleaning efficiency was found slowly decreased when moisture content increased from 5 to $7 \%$ and decreased thereafter rapidly within the experimental range of feed rates, threshing sieve size and drum speed (Fig. 2a, 2d, 2e). It can be observed from Fig. 3a that at a fixed feed rate of $75 \mathrm{kgh}^{-1}$ the cleaning efficiency was decreased slowly as the moisture content was increased up to $7 \%$ and decreased rapidly thereafter up to $91 \%$. Bansal and Lohan( 2009) reported higher cleaning efficiency at lower moisture content in case of seed crops. Simonyan et al., (2006) also reported same result in case of cleaning performance of stationary sorghum thresher. Fulani et al. ( 2013) found higher cleaning efficiency at lower moisture content during threshing of cowpea thresher. Cleaning efficiency was observed slowly decreasing with increase of feed rate in case of all the experimental range of moisture content, threshing sieve size and drum speed (Fig. 2a, 2b, 2c). This may be due to the increase of grain handling due to increase of feed rate. Threshing efficiency was found to be increased rapidly with increase of drum speed with all experimental range of moisture content, feed rate and threshing sieve size (Fig. 2b, 2c, 2d). At a fix moisture content of $5 \%$ the threshing efficiency was increased from 88.8 to $94.5 \%$ as the drum speed increased from 625 to 875 rpm. This may be due to more impact action the chaff were broken down into small parts which were blown away easily because terminal velocity of chaff decreased with its reduced mass. Ajav and Adejumo, 2005 studied performance evaluation of an okra thresher and got the same result as increase in cylinder speed increased the cleaning efficiency. Fulani et al., 2013 obtained high cleaning efficiency at higher drum speed in case of cowpea thresher. Bansal and Lohan ( 2009) also found similar result. Cleaning efficiency was found slowly decreased as the threshing sieve size increased within all experimental range of drum speed (Fig. 2f) and no effect was found with increased threshing sieve size within all the experimental range the moisture content and feed rate (Fig. 2c, 2e). This may be due to the reason that with increase of drum speed threshing efficiency increased and material to be cleaned also increased which reduced the cleaning efficiency. If we fix the feed rate at $75 \mathrm{kgh}^{-1}$ cleaning efficiency was found same as the sieve size increased from 5 to $9 \mathrm{~mm}$ (Fig. 2c).

Optimization of the variables was done by using the design expert 7.0.0 software by taking threshing and cleaning efficiencies as the two responses. The graphical optimization was presented in the Fig 3 a, b, c. By combining the values given in the flagged areas of Fig. $3 \mathrm{a}$, b and $\mathrm{c}$ the optimized values obtained were moisture content $7.79 \%$, feed rate $105.31 \mathrm{kgh}^{-1}$, drum speed 
of $626.9 \mathrm{rpm}$, threshing sieve size of $6.0 \mathrm{~mm}$ by giving the maximum threshing efficiency of $99.5 \%$ and cleaning efficiency of $88.5 \%$. The values were closer to the values obtained in the numerical optimization values. On this basis a new thresher was fabricated with the optimized values.

Testing of the thresher with all the millets: The thresher was operated according to the optimized values of optimized operating parameters. Threshing of six minor millets was done and threshing capacity, threshing efficiency and broken grain were measured. The data were analyzed SPSS (v-10) to assess the suitability of the thresher for the six minor millets and arranged according to Duncan multiple ranges test (DMRT) in the Table 6. The physical parameters of the millets were compared with each other and found significant at 5\% level of significance. The output with different millet was also found significantly different at $5 \%$ level of significance.

The diameter of all the millets was compared with each other for the design of sieve. The result was obtained that diameter of $\mathrm{M}_{1}(2.26 \mathrm{~mm}), \mathrm{M}_{2}(3.41 \mathrm{~mm})$, $\mathrm{M}_{3}(2.35 \mathrm{~mm})$ and $\mathrm{M}_{5}(2.32 \mathrm{~mm})$ are insignificant with each other and $\mathrm{M}_{4}(1.95 \mathrm{~mm})$ and $\mathrm{M}_{6}(1.63 \mathrm{~mm})$ are insignificant to each other but $\mathrm{M}_{1}, \mathrm{M}_{2}, \mathrm{M}_{3}$ and $\mathrm{M}_{5}$ are significantly different as compared to $\mathbf{M}_{4}$ and $\mathbf{M}_{6}$. Sphericity affects the design of outlet and slope of the screen for easy gravity flow. The sphericity of $M_{1}$ (0.481) and $\mathrm{M}_{4}(0.485)$ are insignificant to each other but significantly different from $\mathrm{M}_{2}(0.818), \mathrm{M}_{3}(0.512)$, $\mathrm{M}_{5}(0.544), \mathrm{M}_{6}(0.681)$. Bulk density is required for the design of hopper for feeding of crop. The bulk density of $\mathrm{M}_{1}\left(815.0 \mathrm{~kg} / \mathrm{m}^{3}\right), \mathrm{M}_{4}\left(825.3 \mathrm{~kg} / \mathrm{m}^{3}\right)$ and $\mathrm{M}_{2}(747.0 \mathrm{~kg} /$ $\left.\mathrm{m}^{3}\right), \mathrm{M}_{3}\left(753.7 \mathrm{~kg} / \mathrm{m}^{3}\right)$ are insignificant to each other but significantly different from $\mathrm{M}_{5}\left(895.3 \mathrm{~kg} / \mathrm{m}^{3}\right)$ and $\mathrm{M}_{6}\left(802.0 \mathrm{~kg} / \mathrm{m}^{3}\right)$. Thousand grain weight of all millets was obtained and compared from which the result was obtained that $\mathrm{M}_{3}(2.39 \mathrm{gm}), \mathrm{M}_{4}(2.32), \mathrm{M}_{6}(2.35 \mathrm{gm})$ were insignificant to each other but significantly different from $\mathrm{M}_{1}(2.08 \mathrm{gm}), \mathrm{M}_{2}(4.20 \mathrm{gm})$ and $\mathrm{M}_{5}$ (3.35 $\mathrm{gm})$. The threshing capacity was obtained for each millet. Threshing capacity of $\mathrm{M}_{1}\left(88.7 \mathrm{kgh}^{-1}\right), \mathrm{M}_{3}(95.3$ $\left.\mathrm{kgh}^{-1}\right), \mathrm{M}_{4}\left(95.0 \mathrm{kgh}^{-1}\right)$ and $\mathrm{M}_{6}\left(102.0 \mathrm{kgh}^{-1}\right)$ are insignificant to each other but significantly different from $\mathrm{M}_{2}\left(116.7 \mathrm{kgh}^{-1}\right)$, and $\mathrm{M}_{5}\left(88.7 \mathrm{kgh}^{-1}\right)$. The threshing efficiency of $M_{1}(97.57 \%), M_{4}(97.33 \%)$ and $M_{5}$ $(96.33 \%)$ are different from threshing efficiency of $\mathrm{M}_{2}$ (99.33\%), $\mathbf{M}_{3}(99.40 \%)$ and $\mathrm{M}_{6}(99.40 \%)$. The broken grain percentage of $\mathrm{M}_{2}(0.50 \%), \mathrm{M}_{5}(0.54 \%)$ and $\mathrm{M}_{6}$ $(0.00 \%)$ were significantly different from $\mathrm{M}_{1}(1.70 \%)$, $\mathrm{M}_{3}(1.20 \%)$ and $\mathrm{M}_{4}(1.60 \%)$. The cleaning efficiency of $\mathrm{M}_{1}(97.13 \%), \mathrm{M}_{4}(96.98 \%)$ and $\mathrm{M}_{5}(95.89 \%)$ are different from cleaning efficiency of $\mathrm{M}_{2}(98.96 \%), \mathrm{M}_{3}$ (99.12\%) and $\mathrm{M}_{6}(99.27 \%)$. The values of threshing and cleaning values of the minor millets after testing were higher than the optimized values. This may be due to the reason that at the time of testing for optimization whole crop was fed into, but during the testing of all minor millets, only the ear heads were fed into the thresher.

\section{Conclusion}

The machine was developed and the independent variables were optimized for maximum threshing and cleaning efficiency for threshing of all six minor millets. The optimized values of the independent variables for maximum threshing efficiency $(99.5 \%)$ and cleaning efficiency $(88.5 \%)$ were $7.79 \%$ moisture content, $105.31 \mathrm{kgh}^{-1}$ feed rate, $626.9 \mathrm{rpm}$ cylinder speed, 6 $\mathrm{mm}$ threshing sieve size. The thresher was found suitable for threshing of all six minor millets. It was adopted successfully by the tribal people for threshing of all six minor millets.

\section{ACKNOWLEDGEMENT}

The authors wish to thank Director, ICAR-Central Institute of Agricultural Engineering, Bhopal, MP, India for providing all necessary requirements for the study.

\section{REFERENCES}

Abo El-Naga, M.H.M., El-Gendy, H.A. and Mosa, E.H. (2015). Evaluation of locally threshing machine performance for threshing lentil crop. Misr Journal of Agricultural Engineering, 22(2): 376-388.

Ajav, E.A. and Adejumo, B.A. (2005). Performance evaluation of an Okra thresher. Agricultural Engineering International: the CIGR Ejournal. Manuscript PM 04006, Vol. VII, October.

Anonymous (2001). Grain of truth an analysis. Science and Environmental fortnightly magazine, 15 May: 31-41.

Bansal, N.K. and Lohan, S.K. (2009). Design and development of an Axial flow thresher for seed crops. Journal of Agricultural Engineering, 46(1):1-8

Baryeh, E.A. (2002) Physical properties of millet. Journal of Food Engineering, 51: 39-46.

Crawford, G.W. and Lee, G. (2003). Agricultural origins in the Korean Peninsula. Antiquity, 77(295):87-95.

Fulani, A.U., Kuje, J.Y. and Mohammad, M.I. (2013). Effect of moisture content on performance of a locally fabricated cowpea thresher. Journal of Engineering and Applied Sciences, 5(2): 1-15.

Gbabo, A., Gana, I.M. and Amoto, M.S. (2013). Design fabrication and testing of a millet thresher. Net Journal of Agricultural Science, 1(4): 100-106.

Goyal, R. K., Vishwakarma, R. K. and Wanjari, O.D. (2008). Optimization of pigeon pea dehulling process. Biosystems Engineering, 99(1): 56-61.

Kamble, H.G., Srivastava, A.P. and Panwar, J.S. (2003). Development and evaluation of a pearl millet thresher. Journal of Agricultural Engineering, 40(1): 18-25.

Kushwaha, H.L., Srivastava, A.P. and Singh, H. (2005). Development and performance evaluation of Okra seed extractor. International Commission of Agricultural Engineering, 7: 1-13.

Nath, A. and Chattopadhyay, P.K. (2007). Optimization of oven toasting for improving crispness and other quality attributes of ready to eat potato-soy snack using response surface methodology. Journal of Food Engineering, 80: $1282-1292$. 
Rastogi, N.K., Rajesh, G. and Shamala, T.R. (1998). Optimization of enzymatic degradation of coconut residue. Journal of Science and Food Agriculture, 76: 129-134.

Simonyan, K.J. and Imokheme, P.A. (2008). Development of an axial flow motorized sorghum thresher. Journal of Agricultural Engineering and Technology, 16(2), December: 14-21.

Simonyan, K., Yiljep, Y. and Mudiare, O. (2006). Modelling the cleaning process of a stationary sorghum thresher. Agricultural Engineering International: the CIGR Ejournal. Manuscript P M 06012, Vol. VIII. August, 2006.

Singh, K.P., Kumar, M., Kumar, A. and Srivastava, A.K. (2008). Effect of wire loop spacing, tip height and threshing drum speed on threshing performances of pedal operated VL paddy thresher. Journal of Agricultural Engineering, 45(1),: 12-16.

Singh, K.P., Kundu, S. and Gupta, H.S. (2002). Vivek thresher for madua and madira. Anonymous, Annual report, VPKAS (ICAR), Almora: 88-89.

Singh, K.P., Kundu, S. and Gupta, H.S. (2003). Development of higher capacity thresher for ragi/kodo. Recent trend in millet processing and utilization, CCS, HAU, Hissar, India: 109-116.

Singh, K.P., Pardeshi, I.L., Kumar, M., Srinivas, K. and Srivastva, A.K. (2008). Optimization of machine parameters of a pedal operated paddy thresher using RSM. Biosystems Engineering, 100: 591-600.
Singh, K.P., Mishra, H.N. and Saha, S. (2010). Optimization of machine parameters of finger millet thresher-cumpearler. Agricultural Mechanization in Asia, Africa and Latin America 41 (1): 60-67.

Singh, K.P., Mishra, H.N. and Saha, S. (2010). Optimization of Barnyard millet dehulling process using RSM. Agricultural Mechanization in Asia, Africa and Latin America, 41(2), 15-20.

Singh, K.P., Mishra, H.N., and Saha, S. (2011). Design, development and evaluation of Barnyard millet dehuller. Journal of Agricultural Engineering, 48 (3): 17-25.

Singh, S.K., Agarwal, U.S. and Saxena, R.P. (2004). Optimization of process parameters for milling of green gram (Phaseolusaures). Journal of Food Science and Technology, 41(2): 124-30.

Sinha, J.P., Dhaliwal, I.S., Sinha, S.N. and Dixit, A. (2007). Studies on machine crop parameters for chickpea seed crop threshing. International Commission of Agricultural Engineering, 26 (7): 1-9.

Tiwari, B.K., Jagan Mohan, R. and Bhasan, B.S. (2007). Effect of heat processing on milling of black gram and its end product quality. Journal of Food Engineering, 78: 356-60.

Ushakumari, S.R., Rastogi, N.K. and Malleshi, N.G. (2007). Optimization of process variables for the preparation of expanded finger millet using response surface methodology. Journal of Food Engineering, 82: 35-42. 